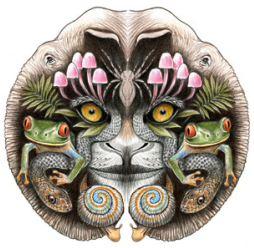

ISSN 0974-7907 (Online) ISSN 0974-7893 (Print)

OPEN ACCESS

\title{
The STATUS OF Chinkara Gazella benNetTII (MAMmalia: CETARTIOdACTYLA: Bovidae) at MAYURESHWAR WildLIFE SANCTUARY, SUPE, BARAMATI, PUNE AND A NOTE ON ITS CURRENT DISTRIBUTION IN THE SOUTHWESTERN REGION OF THE DECCAN PLATEAU OF MAHARASHTRA, INDIA
}

\author{
${ }^{1}$ Nisarg Jagar Pratishthan, Shop No. 2, Mukti Commercial Complex, Jamdar Road, Kasba, Baramati, Taluka Baramati, \\ District Pune, State Maharashtra 413102, India \\ ${ }^{2}$ Bombay Natural History Society, Hornbill House, Shaheed Bhagat Singh Road, Mumbai, Maharashtra 400001, India \\ ${ }^{1}$ batmaheshbat@gmail.com, ${ }^{2}$ sujitsnarwade@gmail.com (corresponding author)
}

Abstract: We conducted monthly road surveys for encounter rates of Chinkara Gazella bennettii in Mayureshwar Wildlife Sanctuary (MWS), Supe Baramati, Pune from June 2011 to May 2012. The sighting records of Chinkara were collected from opportunistic surveys conducted in adjoining areas of the Sanctuary, up to a distance of $200 \mathrm{~km}$ in the southwestern region of the Deccan plateau, Maharashtra. We observed that the Chinkara was facing threats from habitat depletion, including in MWS which was declared a sanctuary for their protection. Road widening projects such as the four lane Pune-Solapur Nationa Highway runs $13 \mathrm{~km}$ on its northern side and a district highway from Ahmednagar to Satara running north-south from the boundary of the Sanctuary have been proposed. Other threats like vehicular movement from tar roads crossing the sanctuary, a proposed underground canal, a major irrigation canal to be constructed along the boundary of the sanctuary, and the increasing number of fenced plots for new residential and other development projects are responsible for the reduction in suitable habitats of the Chinakara. It appears that within a few years, the sanctuary will become an isolated patch of protected grassland, affecting the smooth movement of Chinkara within and beyond the sanctuary limits. Therefore, the remaining population of Chinkara from the entire human dominated landscape will struggle for survival.

Keywords: Chinkara, Deccan plateau, Gazella bennettii, Maharashtra, Mayureshwar Wildlife Sanctuary, Supe.
The Chinkara is found in the plains and low hills of northwestern and central India extending through the open land of the Krishna River. The northeastern limits of Chinkara is Bihar while the southern boundary is the Andhra Pradesh-Karnataka border, and the western border is that of Rajasthan (Prater 1980; Rahmani 1990a). Outside India, it is found in Pakistan (Roberts 1997) and Iran (Ellerman \& Morrison-Scott 1951). Chinkara Gazella bennettii is a browser (Dookia \& Jakher 2007), less gregarious than Blackbuck Antelope cervicapra and lives in small herds in drier regions of the country. Blanford (1888-1891) recorded it in the "whole Bombay Presidency" (present day Maharashtra and Gujarat) with the exception of the Western Ghats and Konkan region.

Under Section 26A of the Wildlife (Protection) Act, 1972 a total of $5.145 \mathrm{~km}^{2}$ area was declared as a Wildlife Sanctuary at Supe, Pune by the Government of Maharashtra in its notification number WLP,1094/CR-

DOI: http://dx.doi.org/10.11609/jott.2653.8.3.8590-8595 | ZooBank: urn:Isid:zoobank.org:pub:D7BD69CD-D19F-47AB-8CD6-F24E5DEA1C99

Editor: L.A.K. Singh, Bhubaneshwar, Odisha, India.

Date of publication: 26 March 2016 (online \& print)

Manuscript details: Ms \# 4006 | Received 25 April 2014 | Final received 09 February 2016 | Finally accepted 24 February 2016

Citation: Gaikwad, M.C. \& S.S. Narwade (2016). The status of Chinkara Gazella bennettii (Mammalia: Cetartiodactyla: Bovidae) at Mayureshwar Wildlife Sanctuary, Supe, Baramati, Pune and a note on its current distribution in the southwestern region of the Deccan Plateau of Maharashtra, India. Journal of Threatened Taxa 8(3): 8590-8595; http://dx.doi.org/10.11609/jott.2653.8.3.8590-8595

Copyright: (c) Gaikwad \& Narwade 2016. Creative Commons Attribution 4.0 International License. JoTT allows unrestricted use of this article in any medium, reproduction and distribution by providing adequate credit to the authors and the source of publication.

Funding: Self funded by Nisarg Jagar Pratisthan

Conflict of Interest: The authors declare no competing interests.
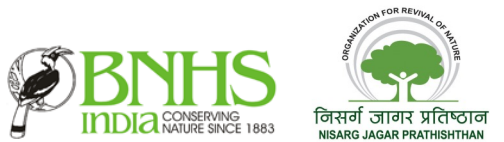

Acknowledgments: We are grateful to Shri Sunil Limaye, Chief Conservator of the Forests (CCF), Wildlife, Pune, Shri Rajendra Nale, former Assistant Conservator of Forests (ACF), Wildlife Pune, Shri Suresh Jagtap and Shri Prabhakar Kukdolkar, former Range Forest Officers (RFO) and all Forest Guards of Mayureshwar Wildlife Sanctuary, Supe and entire Wildlife Division, Pune for their continuous support during the field surveys. We are also thankful to Mr. Dnyaneshwar Ghorpade and Mr. Prasad Magdum, Nisarg Jagar Pratisthan, Phaltan, Satara for their valuable support received during the study period. 
510/F-I, dated 19 August 1997. Recently in year 2015, additional area of 869.37ha has been added to existing Sanctuary. Now total area of the Sanctuary is 1383.92 ha but final notification is awaited. (see Fig. 2) Morgaon Village that is situated $8 \mathrm{~km}$ from Supe is famous for Mayureshwar Ganesh Temple, and hence the Sanctuary is also known as Mayureshwar Wildlife Sanctuary (MWS). The Sanctuary is surrounded by villages like Vadhane, Supe, Kutwalwadi, Kalkhairewadi, Dandwadi, Naroli, etc. This Sanctuary is the only protected area for Chinkara in the Deccan Plateau of Maharashtra and has a significant role in the long-term survival of Chinkara in the human dominated landscape. Our study was initiated with a hope for providing population estimates and recommendations as help for conservation of the Chinkara in Mayureshwar Wildlife Sanctuary and its current distribution range in Deccan Maharashtra.

\section{STUDY AREA}

Mayureshwar Wildlife Sanctuary (MWS), Baramati, Pune is at an altitude of $610 \mathrm{~m}$ from the sea level with an annual rainfall ranging from $300-650 \mathrm{~mm}$. The sanctuary is famous for the Indian Gazelle or Chinkara Gazella bennettii. The sanctuary is located in human dominated landscape surrounded by cropfields and witnesses crop damage by Chinkara. Habitat deterioration due to various developmental activities in surrounding areas is major issue of concern for this Sanctuary (Image 1). The type of habitat of the Sanctuary and Deccan plateau of Maharashtra is southern tropical thorn forest (Champian \& Seth 1968). Extensive surveys were carried out in the southwestern region of the Deccan Plateau of Maharashtra (Fig. 1) along with intensive surveys within MWS (Figs. 2 and 3).

\section{METHODS}

Two road transects of $5 \mathrm{~km}$ distance, one from Supe to Vadhane and the other from Supe to Saswad (Fig. 3) were surveyed on a motorbike ridden at a speed less than $20 \mathrm{~km}$ per hour. We surveyed in the morning from 07:00-07:30 hr during monthly visits and used the direct count method (Rahmani 1990b; Rodgers 1991). Individuals encountered within $500 \mathrm{~m}$ distance on both the sides during road surveys were used for analysis to avoid duplicate counts. Fast moving individuals were

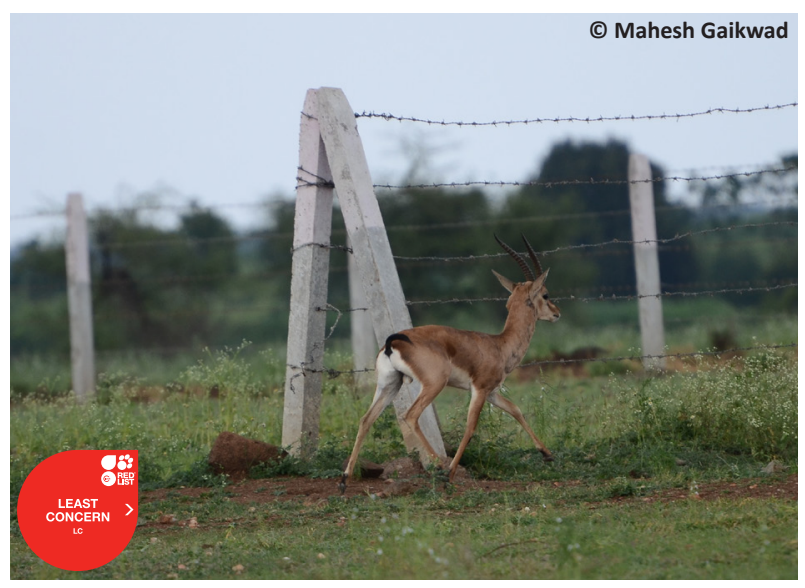

Image 1. The high number of fences for upcoming residential plots near Sanctuary area is one of the major hurdles in smooth movement of Chinkara in the study area.

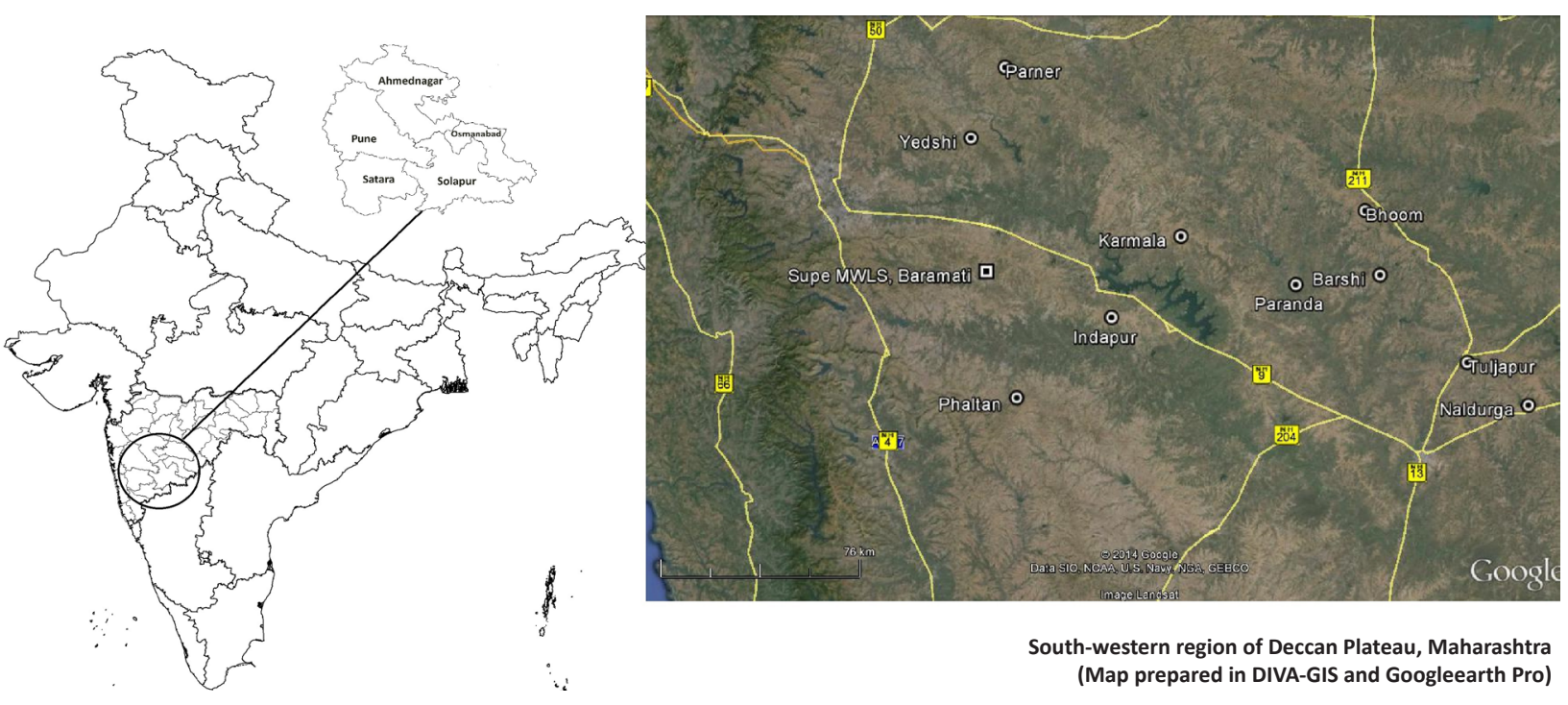

Figure 1. Study area showing Mayureshwar Wildlife Sanctuary with location of Supe (square). Other sites shown in the map indicates distribution range of Chinkara outside MWS where Chinkara count was less than 15 individuals. 


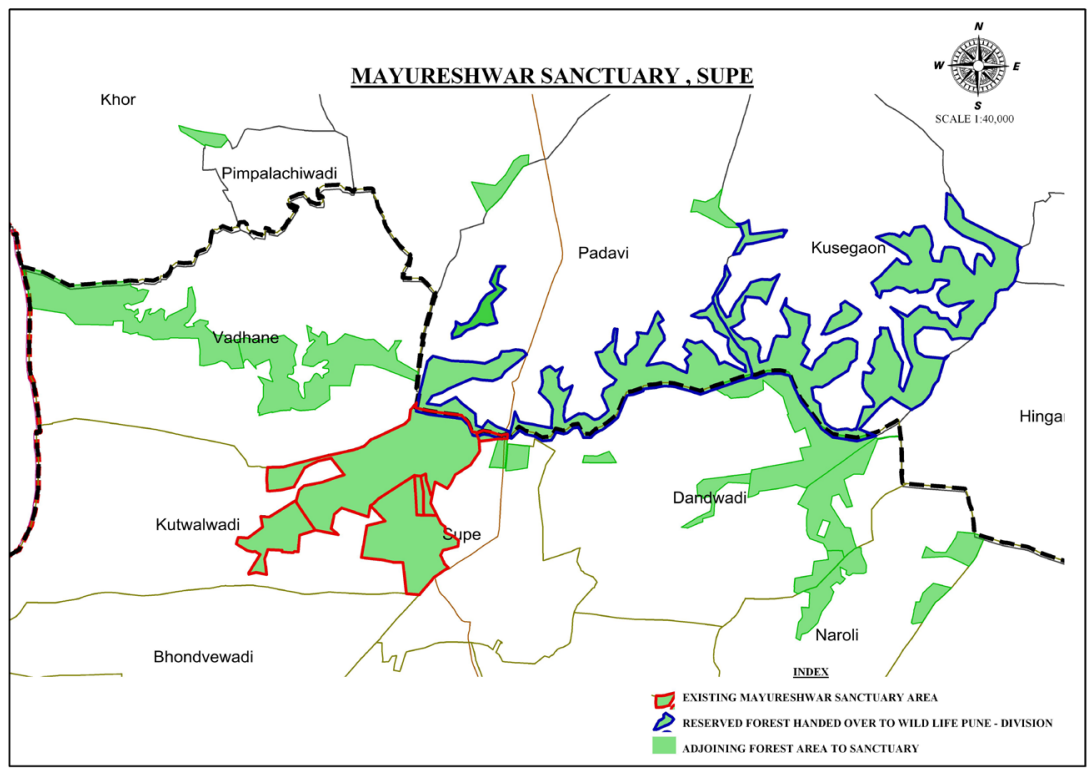

Figure 2. Administrative map of Mayureshwar Wildlife Sanctuary. Few patches of Reserve Forest were handed over to Willdife Division Pune to existing MWS, in year 2015

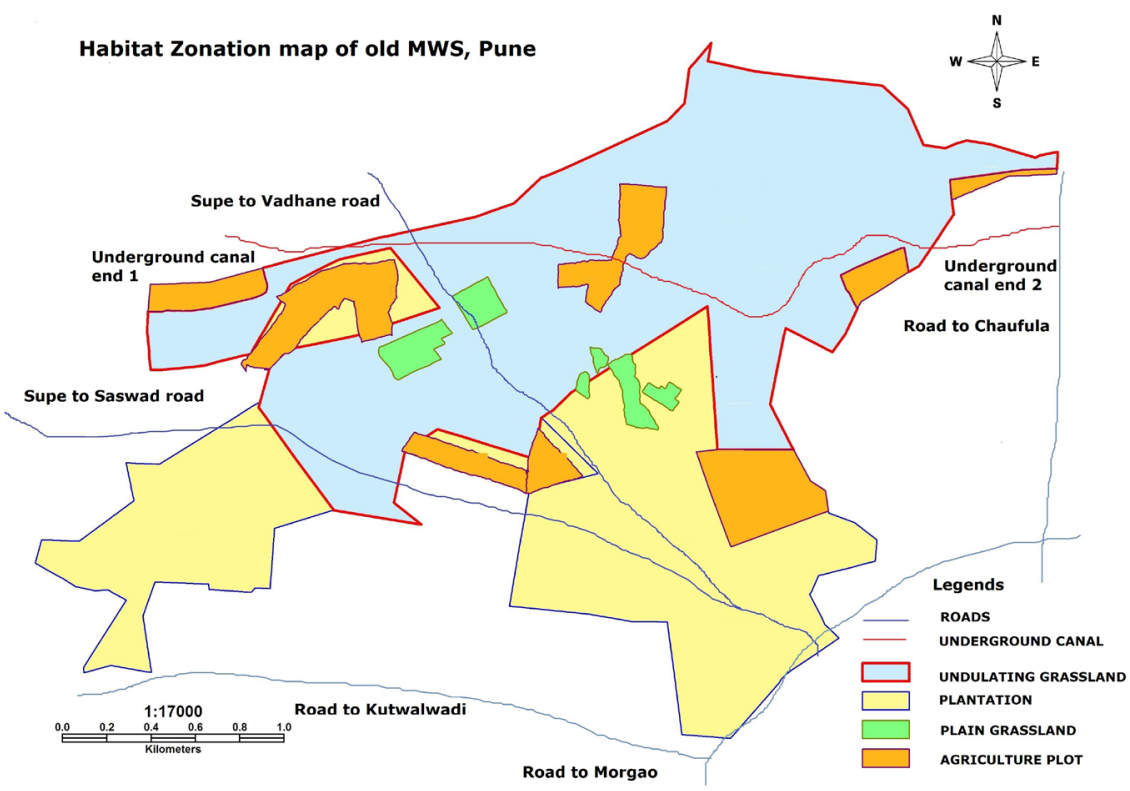

Figure 3. Representative map of habitat Zonation in MWS, Supe, Pune. Showing roads crossing the sanctuary and location of underground canal. not counted if they were crossing the $500 \mathrm{~m}$ distance line from us. The distance was based on visual approximation. Thus, considering $10 \mathrm{~km}$ length and $500 \mathrm{~m}$ width on both sides, we covered about $10 \mathrm{~km}^{2}$ area inside and outside the Sanctuary during each visit from June 2011-May 2012. For the study of social groups and composition we counted four types of groups only, adult male, adult female and fawns or mixed herds (Jakher et al. 2002). Occasional sighting records were collected from the Chinkara distribution range in adjoining areas of the Sanctuary from January 2011 to December 2012.

Notes were made based on the activity of the animals, the structure of the herd and the location of the sighting. Box and whisker plots were prepared in Megastat software (Orris 2015) which shows the numerical data through their quartiles, without making any assumptions about any statistical distribution. The horizontal box-andwhisker plot shows the minimum, first quartile, median, third quartile, and maximum of a set of data from left to right while whiskers represent several possible values. The standard deviation and the standard error of mean have been given separately. Distribution map (Fig. 1) is developed using GPS coordinates in DIVA-GIS software (Hijmans 2012). We prepared an excel graph of the 


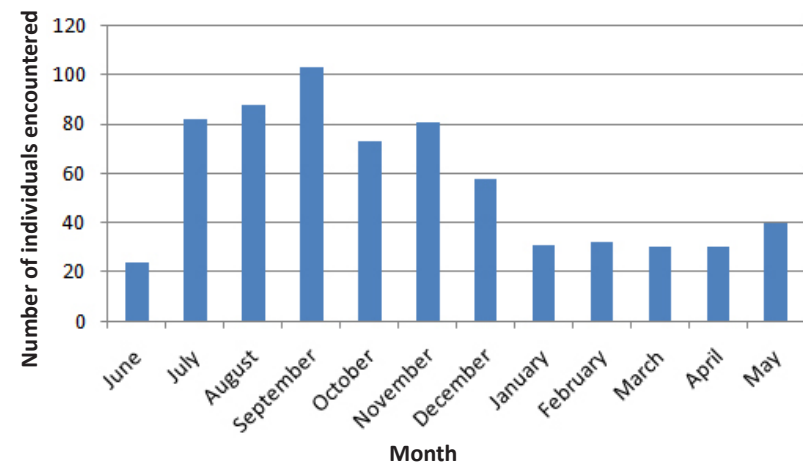

Figure 4. Month-wise population change in Chinkara at Mayureshwar Wildlife Sanctuary during the study period (June 2011 to May 2012.

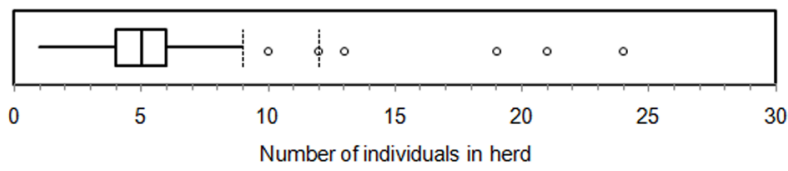

Figure 6. Box plot displaying variation in herd size or visual estimation of group size without any assumptions of the statistical distribution

number of individuals sighted in three different habitat plots - in the grassland, agricultural land and plantation in the Sanctuary (Fig. 5).

\section{RESULTS}

According to Prater (1980) the average group size of Chinkara is three but occasionally herds of up to 25 animals were also seen. In Pakistan, Roberts (1997) also found the small group size of up to three animals and only once saw seven individuals together. Rahmani (1990) and Dookia (2007) encountered larger herd size of 7-8 animals together in Thar Desert, Rajasthan. Groups of Chinkara never exceeded beyond six individuals in either season, in the central Indian region (Bagchi et al. 2008) but Dookia \& Jakher (2013) reported a herd size of up to 24 once in Western Rajasthan.

The average herd size of Chinkara at Supe was 5.007 with a standard deviation of 7.04 and standard error of mean 1.82. Herd size, comprising 5-12 species were common and herds having more than 20 individuals were seen occasionally (Fig. 6). A total of 130 herds were seen within which 96 herds were smaller than average size and in 15 were larger than average size and occasionally up to 24 individuals (Fig. 6). Usually, large mixed herds were observed in open grassland areas (Fig. 5) while a few times, herds were seen under plantation during hot days. Post winter and summer, the population was seen to go down as low as 25 individuals

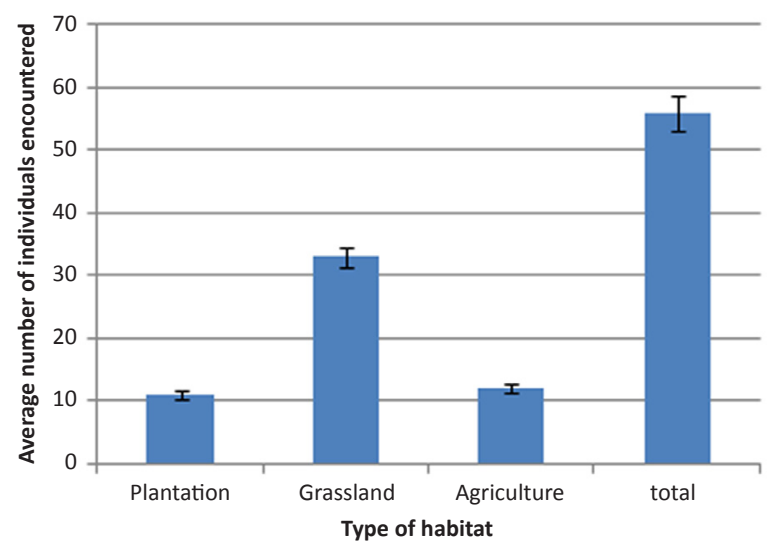

Figure 5. Number of individuals encountered in different habitats (with $\mathbf{5 \%}$ error bars) at Mayureshwar Wildlife Sanctuary

in the sanctuary, as the Chinkara move to adjoining farmland areas (Fig. 5). During the monsoon, more than a hundred individuals were encountered on monthly visits (Fig. 4). The Fawns were sighted exclusively in the sanctuary area in smaller herds throughout the year. During the yearlong study conducted from May 2011 to June 2012, we encountered a total of 155 Males, 292 females and 366 unidentified individuals and 77 fawns. The natural predators of Chinkara in the study area are Grey Wolf Canis lupus, Striped Hyena Hyaena hyaena, Golden Jackal Canis aureus and Jungle Cat Felis chaus.

\section{Discussion}

During our study, we became aware that MWS is facing threats due to the following issues:

1. During the last one decade, the human population in the surrounding areas of the MWS, i.e., Baramati and Indapur talukas (tehsils) of Pune District, Maharashtra has increased from 56,000 in 1991 to 79,000 in 2011 resulting in more pressure on the available habitat for Chinkara.

2. Two roads cross the Sanctuary, one Supe to Saswad and another from Supe to Vadhane (Map - 2). Approximately, 100 to 150 vehicles were seen using these roads daily (Image 2 ).

3. An ongoing work of underground canal which will have a huge network of smaller channels all over the landscape is another issue for habitat fragmentation. Changes in land use pattern due to industrial and agricultural intensification will make the habitat unsuitable for the Chinkara. Change in agricultural practices such as shifting from traditional crops to cash crops like sugarcane is affecting the suitable habitat of Chinkara. 


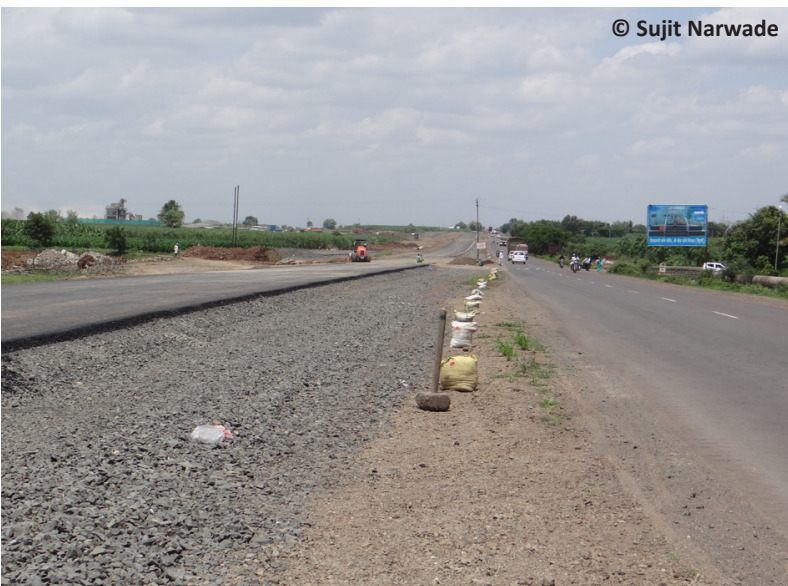

Image 2. Four laning of Solapur Pune highway restricted the movement of Chinkara.

4. The occasional hunting of Chinkara is learnt to be also an issue of concern, although we did not come across any case filed by the forest department, during the study period.

5. We have not seen any incidence of killing of Chinkara by free ranging dogs, but we came across a few incidences of dogs chasing the young ones of Chinkara.

6. Tourists throw plastic bags, bottles, which can be swallowed by these ungulates and which is also a threat to the natural vegetation.

The reasons behind the fluctuations of Chinkara population in MWS area could be as follows:

1. Ongoing construction activities of a proposed underground water tunnel going on for the last 12 years.

2. Overgrazing by cattle, especially by a large number of goats and sheep resulting in the competition for the food resources of Chinkara. Plantation of exotic trees like Gliricidia in grassland areas is reducing the suitable habitat of grassland species, and there is a need to have a policy of no plantations in grassland areas (Image 3).

3. We found that the distribution range of Chinkara is shrinking from non protected areas which is becoming more fragmented. Small populations of Chinkara were sighted only in 11 areas at a distance of $200 \mathrm{~km}$ from MWS as shown on Fig. 1 and in Table 1.

4. It was found that grasslands in the study area are threatened because of rampant development, especially because of proposed windmills coming on undulating slopes, the solar power plants, urbanization and industrialization in the study area (Narwade et al. 2013).

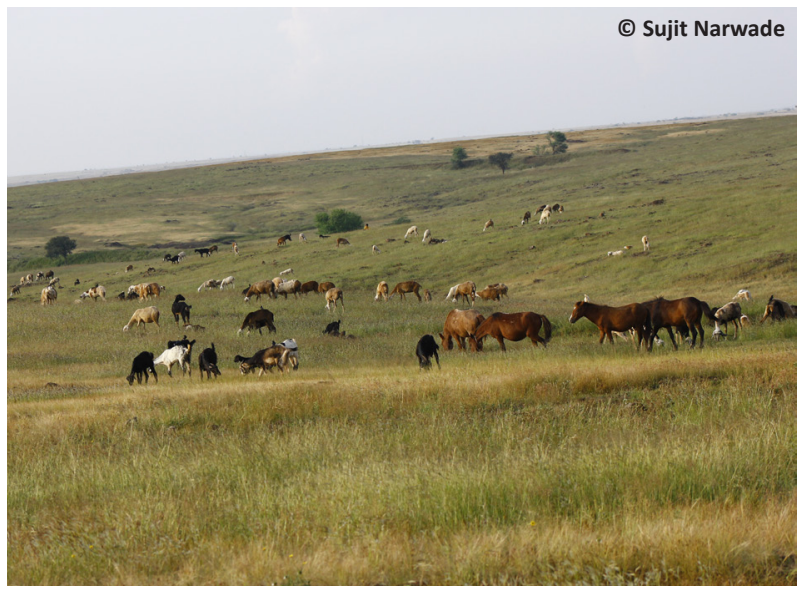

Image 3. Overgrazing by cattle resulting in competition for food resources of Chinkara (photo taken at non protected land at Naldurg, Tuljapur, District Osmanabad $225 \mathrm{~km}$ aerial distance from the MWS.

\section{RECOMMENDATIONS}

Small patches of protected areas are the last hope for survival for species like the Great Indian Bustard Ardeotis nigriceps, Indian Blackbuck Antilope cervicapra and Chinkara Gazella bennettii. We suggest the following measures for the effective conservation of Chinkara in the Deccan plateau of Maharashtra, India.

For management within the sanctuary:

1. Regular patrolling and putting up of sign boards of cautions for vehicles inside and outside the Sanctuary, to avoid road-kill incidences of the wild animals.

2. Restoration of grasslands, especially those possible under Draught Prone Area Programme (DPAP) plots.

3. Need to strengthen the capacity of the local forest department for better management of the Sanctuary with Chinkara as the focussed animal.

4. Conduct regular Chinkara population surveys within and outside the sanctuary.

5. Awareness material should be made available in regional language for the villagers, drivers and students.

6. Government of Maharashtra has decided to increase size of the MWS by adding adjoning private lands in the existing Sanctuary area. But local people do not want to sale their land and started protesting against this move. Therefore, Instead of acquiring private lands, adjoining patches of reserve forests can be included in the sanctuary area.

The following recommendations are made specifically for the management of Chinkara outside the sanctuary:

1. Development of alternative habitat: 


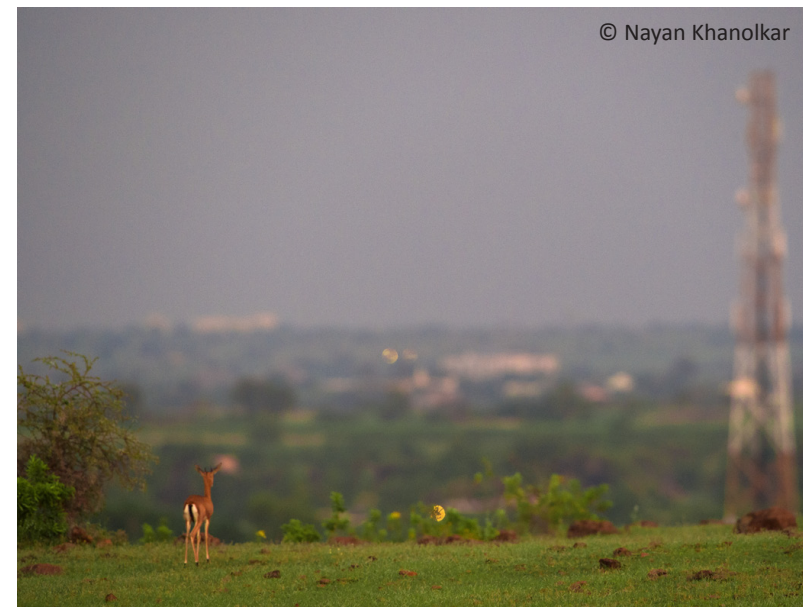

Image 4. Chinkara in highly human dominated landscape at Indapur

afforestation by the forest department should aim at species conservation. Suitable replacement of unplanned afforestation may be taken up.

2. Additional participatory benefits and involvement other than compensation should be given to local villagers at gram panchayat level, so that people feel proud to have Chinkara in their surroundings. For example, Chinkara is benefited from the participation of locals in the "People declared Sanctuary" at Indapur area of Maharashtra.

3. Traditional monitoring involving local people as well radio collaring programme for Chinkara should be initiated to track movement in human-dominated landscape (Image 4).

4. Habitat management schemes may be encouraged according to the requirements of Chinkara for its breeding, resting and foraging activities.

5. A network of local people may be set up for regular monitoring of the Chinkara population.

6. Cooperation among local people, district administrative staff and forest personnel, NGOs and educational institutes for the protection, research and monitoring of Chinkara need to be strengthened and coordinated.
7. There is a need to study the impact of land use change on Chinkara due to factors like irrigation canal (Chatterji \& Saxena 1988).

\section{REFERENCES}

Bagchi, S., S.P. Goyal \& K. Shankar (2008). Social organisation and population structure of ungulates in a dry tropical forest in western India (Mammalia, Artiodactyla). Mammalia 72: 44-49.

Blanford, W.T. (1888). The Fauna of British India, including Ceylon and Burma. Part II Mammalia. Taylor and Francis, London, i-xx, +617pp, i-xiii.

Champion, H.G. \& S.K. Seth (1968). Southern Thorn Forest. 229-232 Pp. In: A Revised Survey of Forest Types of India, Government of India, New Delhi. i-xxvi Pp. 404

Chatterjee, P.C. \& S.K. Saxena (1988). Canal irrigation in arid zone of Rajasthan and its ecological implications, pp. 223-258. In: Prakash, I. (ed.). Desert Ecology. Scientific Publishers, Jodhpur, India, 313pp.

Dookia, S. (2007). Participation of local villagers in conservation of Indian Gazelle or Chinkara (Gazella bennettii) in Thar Desert of Rajasthan, India. Project Technical Report submitted to the Ruffords Small Grants Foundation, 32pp.

Dookia, S. \& G.R. Jakher (2007). Food and feeding habit of Indian Gazelle (Gazella bennettii), in the Thar Desert of Rajasthan. Indian Forester 133(10): 1327-1340.

Dookia, S. \& G.R. Jakher (2013). Social organization and population dynamics of Indian Gazelle (Gazella bennettii) in Thar Desert of Rajasthan, India. Tiger Paper 40(1): 5-14.

Ellerman, J.R. \& T.C.S. Morrison-Scott (1951). Checklist of Palearctic and Indian Mammals. 1758 to 1946. Fisted. The British Museum (Natural History), London, 810pp.

Hijmans, R.J., L. Guarino \& P. Mathur (2012). DIVA-GIS Version 7.5. http://www.diva-gis.org/

Jakher, G.R., S. Dookia \& B.R. Dookia (2002). Herd Composition and population dynamics of Indian Gazelle Gazella bennetti (Sykes, 1831 ) in Gogelao Enclosure (Nagaur), Rajasthan. Zoos' Print Journal 17(11): 936-938; http://dx.doi.org/10.11609/JoTT.ZPJ.17.11.936-8

McGill, R., J.W. Tukey \& W.A. Larsen (1978). "Variations of Box Plots". The American Statistician 32(1): 12-16.

Narwade, S.S., M.C. Gaikwad \& K.M. Fartade (2013). Status survey of harriers in south-western region of Deccan Plateau of Maharashtra. Newsletter for Bird Watchers 53(2): 28-30.

Orris, J.B. (2015). MegaStat - an Excel add-in programme. Mega Stat User's Guide. Butler University, 72pp.

Prater, S.H. (1980). The Book of Indian Animals. Third edition (reprinted with corrections), Bombay Natural History Society, Bombay, 324pp.

Rahmani, A.R. (1990a). Distribution, density, group size and conservation of the Indian Gazelle or Chinkara Gazella bennetti (Sykes, 1831) in Rajasthan, India. Biological Conservation 51: 177189.

Rahmani, A.R. (1990b). Distribution of the Indian Gazelle or Chinkara, Gazella bennetti (Sykes) in India. Mammalia 54(4): 605-619.

Rodgers, W.A. (1991). Techniques for Wildlife Census in India: A Field Manual. Wildlife Institute of India, Dehradun, 82pp.

Roberts, T.J. (1997). The Mammals of Pakistan. Revised Edition. Oxford University Press, Karachi, 525pp. 